\title{
Antidepressant-Like Effect of Tetramethylpyrazine in Mice and Rats
}

\author{
Lijian Yu ${ }^{1 \#^{*}}$, Xiaodan Jiang ${ }^{1}$, Mingneng Liao ${ }^{1}$, Rundi Ma ${ }^{1 \#}$, Tingxi Yu ${ }^{1,2 \# *}$ \\ ${ }^{1}$ Key Laboratory of Marine Materia Medica, Guangdong Ocean University, Zhanjiang, China; ${ }^{2}$ Cell Biology Group, Department of \\ Surgery, Department of Pathology, University of Maryland School of Medicine and Baltimore Veterans Affairs Medical Center, \\ Baltimore, USA. \\ Email: ywyj9578@sohu.com, yutingxi@yahoo.com
}

Received February 23 ${ }^{\text {rd }}, 2011$; revised April 6 ${ }^{\text {th }}, 2011$; accepted April $20^{\text {th }}, 2011$.

\begin{abstract}
The aim of this study was to investigate the potential antidepressive-like effect of tetramethylpyrazine (TMP), one of available blood-activating and stasis-eliminating components from traditional Chinese medicines, and its mechanism of the antidepressant-like action. Forced-swimming, tail-suspension, reserpine-induced hypothermia, akinesia and ptosis, 5-hydroxytryptophan (5-HTP)-induced head-twitch, and potentiation of noradrenaline (NE) toxicity tests, were performed to assess the potential antidepressant-like activity of TMP and to study the mechanism by which TMP exerts the antidepressant-like action. Intragastric (ig) administration of TMP markedly reduced the duration of immobility during forced-swimming tests and tail-supension test in rats and mice. TMP partialy reversed reserpine-induced hypothermia, ptosis and akinesia, and potentiated NE toxicity in mice, and these are similar to those of clomipramine; however, TMP did not potentiate 5-HTP-induced head-twitch response (HTR) in mice, and this is different from that of fluoxetine (FLU). The present data provide evidences that TMP possesses potent antidepressant-like activity, and it might be an adrenergic component of pharmacological activity, and its mechanism of antidepressant-like action is similar to that of clomipramine, and different from that of FLU.
\end{abstract}

Keywords: Tetramethylpyrazine (TMP), Antidepressive-Like Activity, Mice, Rats, Monoaminergic Neurotransmitter

\section{Introduction}

Currently, depression is one of most significant major public health problems, and is a serious and common medical condition affecting physical health, mood, and thoughts. Major depression is characterized for symptoms at the psychological, behavioral and physiological levels. Antidepressants are commonly prescribed for depression and other affective disorders, although the molecular and cellular mechanisms by which these agents exert their therapeutic effects are not well understood. Despite the advances in the treatment of depression with selective serotonin reuptake inhibitors (SSRIs) and serotonin and norepinephrine reuptake inhibitors (SNRIs), there continue to be many unmeet clinical needs with respect to both efficacy and side effects. To address these needs, antidepressants with novel mechanisms and without side effects are in great demand.

Some medicinal plants and traditional Chinese medicines and herbs or their extracts have showed antide-

"The authors contributed equally to this work. pressant-like effects [1-4]. Ligusticum chuanxiong Hort has the action of activating blood, regulating qi and expels wind [5]. Chuanxiongzine, 2,3,5,6-tetramethylpyrazine (TMP) (Figure 1), was isolated from several traditional Chinese medicines, such as Ligusticum Chuanxiong Hort, Curcuma aromatica Salisb, and Jatropya podagrica Hook [6]. TMP is colorless needle crystal, and is soluble in hot water.

TMP can inhibit L-type calcium-channel current and release of intracellular calcium store in hippocampal neuronal cells, and exerts nerve protective effect [7]. Chinese scientists have contributed a lot to its investigation, and as an available blood-activating and stasiseliminating component, it has been extensively applied to the treatment of vascular diseases of heart and brain, and obtained excellent efficiency in China [8].

\section{Materials and Methods}

\subsection{Drugs}

TMP, reserpine, and clomipramine hydrochloride were 
<smiles>Cc1nc(C)c(C)nc1C</smiles>

Figure 1. Chemical structure of TMP.

purchased from National Institute for the Control of Pharmaceutical and Biological Products (Beijing, China), and fluoxetine (FLU) hydrochloride was purchased from Eli Lilly and Company Limited (USA). 5-Hydroxytryptophan (5-HTP) was purchased from Jinjinyao Amino Acid Co. Ltd (Tianjin, China), and NE bitartrate injection purchased from Grass Plant Technology Co. Ltd. (Xian, China).

\subsection{Animals}

Special pathogen free (SPF) adult male Sprague-Dawley (SD) strain rats weighing $180-220 \mathrm{~g}$ and Kunming (KM) mice weighing 18 - $22 \mathrm{~g}$ purchased from the Experimental Animal Center of Guangdong Medical College (experimental animal license SCXKyue 2007-2008A034, No.0001909; Zhanjiang, China), were used across all the experiments. They had free access to tap water and standard laboratory food unless otherwise stated. Housing conditions were controlled, temperature was maintained at $22^{\circ} \mathrm{C} \pm 11^{\circ} \mathrm{C}$ with approximately $60 \%$ relative humidity. They were kept on a reversed 12/12 h light/dark cycle (light 07:00 - 19:00 h). Animals were acclimated to the animal quarters for 1 week (for rats) or 3 days (for mice) before any experimental procedure. All the animals were treated in compliance with "Guidance Suggestion for the Care and Use of Laboratory Animals" issued by The Ministry of Science and Technology of People's Republic of China.

\subsection{Forced-Swimming Test}

Measurement of immobility time was carried out by observing the motoric activity of the mice or rats, which were placed in a pool of water. A glass cylinder, $15 \mathrm{~cm}$ (for mice) or $30 \mathrm{~cm}$ (for rats) in diameter, height $20 \mathrm{~cm}$ (for mice) or $40 \mathrm{~cm}$ (for rats), was filled with water to a height of $12 \mathrm{~cm}$ (for mice) or $24 \mathrm{~cm}$ (for rats). The temperature of water was $25^{\circ} \mathrm{C} \pm 1^{\circ} \mathrm{C}$. Each mouse or rat received twice a respective dose of FLU $(20 \mathrm{mg} / \mathrm{kg}$, ig) or TMP (20, 40, $80 \mathrm{mg} / \mathrm{kg}$, ig) $17 \mathrm{~h}$ and $7 \mathrm{~h}$ (for FLU) or 30 (for rats) or 10 (for mice) min (for TMP) before the forced-swimming test. This dose of FLU was chosen because it had been shown to be differentially effective in HR vs LR animals [9]. The mice or rats in controls received ip injection of physiological saline instead of TMP. And then the animals were subjected to the tests. Measurement was carried out for six (for mice) or five min (for rats). For mice, the first two min the animal was allowed to adjust to the new conditions; after these two min, the immobility time that alternated with conditions of enhanced motor activity was measured. Immobility time was measured with a stopwatch for the next four min. For rats, no time the animal was allowed to adjust to the new conditions. Immobility time is the time during which the animal floated on the surface with front paws together and made only those movements which were necessary to keep afloat. Shorter immobility time is an indicator of the stronger antidepressant effect of the tested substance [10-12].

\subsection{Tail-Suspension Test}

The tail suspension test was based on the method of Steru et al. [13]. Each mouse received twice a respective dose of FLU (20 mg/kg, ig) or TMP $(20,40,80 \mathrm{mg} / \mathrm{kg}$, ip) $17 \mathrm{~h}$ and $7 \mathrm{~h}$ (for FLU, ig) or $10 \mathrm{~min}$ (for TMP, ig) before the tail-suspension test, the mice in control received ig physiological saline instead of TMP, and the animals were subjected to the test 10 min later. A cord of about $50 \mathrm{~cm}$ in length was stretched between two metal tripods at a height of ca $70 \mathrm{~cm}$, to which the mice were attached by the tail with sticky tape. After the initial period (the first two min) of vigorous motor activity, the mice became still and the immobility time was measured with a stopwatch for a total duration of 4 min $[13,14]$. Mice were considered immobile when they hung passively and completely motionless.

\subsection{Induction and Measurement of Hypothermia, Akinesia and Ptosis}

Mice were assigned randomly into six matched groups (each consisting of 12 animals) based on rectal temperature (for hypothermia test) or body weight (for akinesia and ptosis tests) before onset of the test. Group1 (control) was treated with physiological saline, and maintained under identical conditions to other groups for use as control. Group 2 (reserpine) was given reserpine alone (2 $\mathrm{mg} / \mathrm{kg}$, ip). Group 3 (clomipramine) was given both clomipramine hydrochloride $(40 \mathrm{mg} / \mathrm{kg} \times 2)$ and reserpine ( $2 \mathrm{mg} / \mathrm{kg}$, ip). Group 4, 5, 6 (TMP) were given both TMP $(20,40,80 \mathrm{mg} / \mathrm{kg} \times 2)$ and reserpine ( $2 \mathrm{mg} / \mathrm{kg}$, ip), respectively. Clomipramine hydrochloride or TMP were administered ig twice $24 \mathrm{~h}$ and 30 min prior to reserpine, and then the mice were treated with reserpine.

At $60 \mathrm{~min}$ after the injection of reserpine the mice were placed in a circle $7.5 \mathrm{~cm}$ in diameter to observe for $30 \mathrm{~s}$, the number of mice out of circle in each group was calculated [15]. The degree of ptosis of each animal was recorded at $90 \mathrm{~min}$ after the injection of reserpine. For the evaluation of ptosis, mice were placed on a shelf (20 $\mathrm{cm}$ above the bench top). The degree of ptosis was rated 
according to the following rating scale: 0 , eyes open; 1 , one-quarter closed; 2 , half closed; 3 , three-quarters closed; and 4 , completely closed $[2,16]$. The rectal temperature of each animal was measured with an electrical thermometer at 2, 4, $6 \mathrm{~h}$ after the injection of reserpine $[4,17]$.

\subsection{Measurement of HTR Induced by 5-HTP}

\subsubsection{Effect of TMP on HTR Induced by 5-HTP}

Male KM mice were assigned randomly into six matched groups ( $n=12$ animals in each group) based body weight before onset of the test: control, 5-HTP, FLU, and TMP groups. FLU (40 mg/kg) or TMP (20, 40, $80 \mathrm{mg} / \mathrm{kg}$ ) were administered ig twice $24 \mathrm{~h}$ and 30 min prior to 5HTP, and 30 min later the mice were ip injected with 5HTP $(200 \mathrm{mg} / \mathrm{kg})$. Control was treated with physiological saline, and maintained under identical conditions to other groups. The number of HTR were counted for $8 \mathrm{~min}$ (from 15 to $23 \mathrm{~min}$ ) after the injection of 5-HTP. The total number of HTP per experiment was counted for each mouse [18].

\subsubsection{Effect of FLU + TMP on HTR Induced by 5-HTP}

Male KM mice were assigned randomly into five matched groups ( $n=10$ animals in each group) based body weight before onset of the test: control, 5-HTP, FLU, TMP, and FLU + TMP groups. FLU (40 mg/kg), TMP $(80 \mathrm{mg} / \mathrm{kg})$ or FLU $(40 \mathrm{mg} / \mathrm{kg}$ ) following TMP (80 $\mathrm{mg} / \mathrm{kg}$ ) were administered ig twice $24 \mathrm{~h}$ and $30 \mathrm{~min}$ prior to 5-HTP, and $30 \mathrm{~min}$ later the mice were ip injected with 5-HTP $(200 \mathrm{mg} / \mathrm{kg})$. Control was treated with physiological saline, and maintained under identical conditions to other groups. The number of HTR was counted as above mentioned.

\subsection{Potentiation of NE Toxicity Test}

Mice were assigned randomly into six matched groups (each consisting of 12 animals) based on body weight before onset of the test. Group 1 (control) was treated with physiological saline, and maintained under identical conditions to other groups for use as control. Group 2 (NE) was given NE bitartrate alone ( $4.0 \mathrm{mg} / \mathrm{kg}$, ip). Group 3 (clomipramine) was given both clomipramine $(40 \mathrm{mg} / \mathrm{kg}$ $\times 2)$ and NE bitartrate (4.0 mg/kg, ip). Group 4, 5, 6 (TMP) were given both TMP $(20,40,80 \mathrm{mg} / \mathrm{kg} \times 2)$ and NE bitartrate ( $4.0 \mathrm{mg} / \mathrm{kg}$, ip), respectively. Clomipramine or TMP were administered ig twice $24 \mathrm{~h}$ and $30 \mathrm{~min}$ prior to NE bitartrate, and then the mice were treated with NE bitartrate. Lethality (number of mice which died/total number of mice) was recorded and calculated $48 \mathrm{~h}$ after the injection of NE bitartrate.

\subsection{Statistical Analysis}

Results were expressed as the mean \pm standard deviation
(SD) unless otherwise stated. The data were analyzed by one-way ANOVA, followed by Dunnett's $t$-test. Comparisons of lethality and akinesia among groups were made according to $\chi^{2}$-test. Signicant difference was determined when $P<0.05$.

\section{Results}

\subsection{Effects of ig Administration of TMP on the Immobility Time in Forced-Swimming Animal Models of Depression}

Figures 2 and 3 show the effects of TMP and FLU on the duration of immobility in the forced swim tests. When compared with the control group, TMP at the doses of 20,40 , and $80 \mathrm{mg} / \mathrm{kg}$ reduced the duration of immobility by $11.5 \%, 15.5 \%$ and $24.0 \%(P<0.05)$ (for rats), and $21.5 \%, 29.7 \%$, and $39.9 \%(P<0.05)$ (for mice), respectively. Similar effects were observed for treating the rats and mice with classical antidepressant FLU at the dose of $20 \mathrm{mg} / \mathrm{kg}$ which served as a positive control of the experiment. The reduction in the duration of immobility given with FLU $20 \mathrm{mg} / \mathrm{kg}$ ) was $34.1 \%$ (for rats) and $37.0 \%$ (for mice), respectively. TMP at the dose of $80 \mathrm{mg} / \mathrm{kg}$ was as effective as the positive control (FLU, $20 \mathrm{mg} / \mathrm{kg}$ ) in these tests.

\subsection{Effects of ig Administration of TMP on the Immobility Time in Tail-Supension Animal Model of Depression}

Figure 4 shows the effects of TMP and FLU on the duration of immobility in the tail suspension test. TMP at the doses of 40 and $80 \mathrm{mg} / \mathrm{kg}$ significantly reduced the dura-

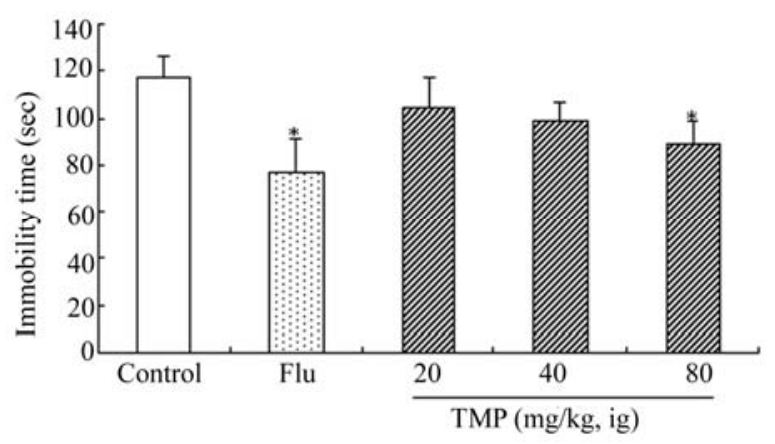

Figure 2. Effect of ig administration of TMP on the immobility time during forced-swimming test in rats. Each rat received twice a respective dose of $F L U(20 \mathrm{mg} / \mathrm{kg}$, ig) or TMP (20, 40, $80 \mathrm{mg} / \mathrm{kg}$, ig) $17 \mathrm{~h}$ and $7 \mathrm{~h}$ (for FLU) or $30 \mathrm{~min}$ (for TMP) before the forced-swimming test, the rats in control received ig administration of physiological saline instead of TMP. And the measurement of immobility time was carried out by observing the motoric activity of the rats as described in "Materials and Methods". Values are expressed as the means \pm SEM of 12 animals per group. Data were analyzed with SPSS 10.0 software. $^{*} P<0.05$, vs control. 


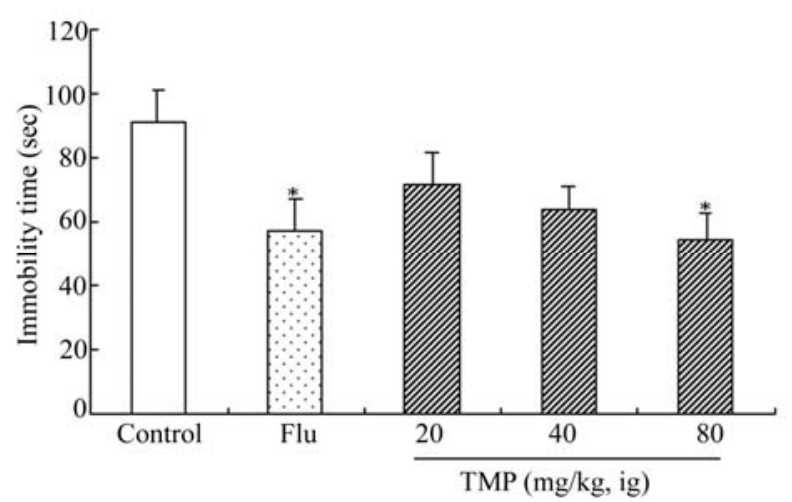

Figure 3. Effect of ig administration of TMP on the immobility time during forced-swimming test in mice. Each mouse received twice a respective dose of FLU $(20 \mathrm{mg} / \mathrm{kg}$, ig) or TMP (20, 40, $80 \mathrm{mg} / \mathrm{kg}$, ig) $17 \mathrm{~h}$ and $7 \mathrm{~h}$ (for FLU) or $10 \mathrm{~min}$ (for TMP) before the forced-swimming test, the mice in control received ig administration of physiological saline instead of TMP. And the measurement of immobility time was carried out by observing the motoric activity of the rats as described in "Materials and Methods". Values are expressed as the means \pm SEM of 12 animals per group. Data were analyzed with SPSS 10.0 software. ${ }^{*} P<$ 0.05 vs control.

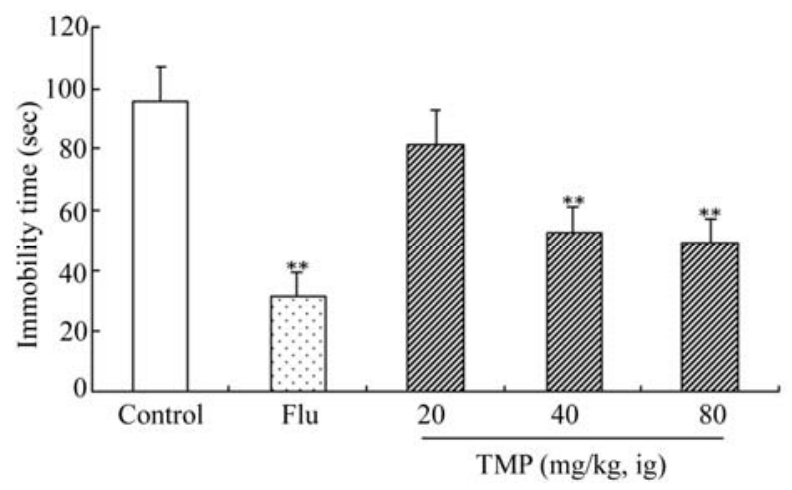

Figure 4. Effect of ig administration of TMP on the immobility time during tail-suspension test in mic. Each mouse received twice a respective dose of FLU $(20 \mathrm{mg} / \mathrm{kg}$, ig) or TMP (20, 40, $80 \mathrm{mg} / \mathrm{kg}$, ip) $17 \mathrm{~h}$ and $7 \mathrm{~h}$ (for FLU, ig ) or 10 min (for TMP, ig) before the tail-suspension test, the mice in control received ig administration of physiological saline instead of TMP. And the measurement of immobility time was carried out by observing the motoric activity of the mice as described in "Materials and Methods". Values are expressed as the means \pm SEM of 12 animals per group. Data were analyzed with SPSS 10.0 software. ${ }^{*} \boldsymbol{P}<0.05$ vs control.

tion of immobility time by $45.4 \%$ and $48.9 \%$, respectively. Under the same experimental conditions, FLU at the dose of $20 \mathrm{mg} / \mathrm{kg}$ also produced a significant (66.9\%) reduction in the duration of immobility when compared with the control group. TMP at the doses of 40 and 80 $\mathrm{mg} / \mathrm{kg}$ was as effective as the positive control, FLU.

\subsection{Partial Reversal of Reserpine-Induced Hypothermia in Mice by TMP}

Reserpine $(2.0 \mathrm{mg} / \mathrm{kg})$ induced a considerable fall (to about 32.5 ) in the body temperature 4 hours after its administration (Figure 5). TMP, given 4 hours after reserpine administration at the doses of 20, 40 and 80 $\mathrm{mg} / \mathrm{kg}$, weakened the hypothermic action (Figure 5). This effect was stronger for the $80 \mathrm{mg} / \mathrm{kg}$ dose.

\subsection{Antagonism of Reserpine-Induced Akinesia and Ptosis in Mice by TMP}

Tables 1 and 2 show the effects of TMP and clomipramine on reserpine-induced akinesia and ptosis in mice. When compared with the clomipramine control group, TMP at the doses of 40 and $80 \mathrm{mg} / \mathrm{kg}$, and clomipramine at the dose of $40 \mathrm{mg} / \mathrm{kg}$, significantly antagonized akinesia and ptosis induced by reserpine in mice. TMP at the dose of $20 \mathrm{mg} / \mathrm{kg}$ significantly antagonized ptosis, but not akinesia.

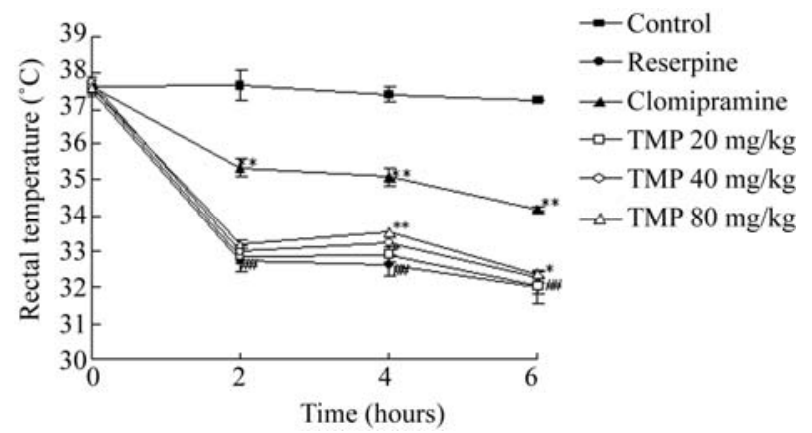

Figure 5. Partial reversal of reserpine $(2.0 \mathrm{mg} / \mathrm{kg})$-induced hypothermia in mice by TMP. Clomipramine hydrochloride or TMP was administered ig twice $24 \mathrm{~h}$ and $30 \mathrm{~min}$ prior to reserpine, and then the mice were treated with reserpine ( $2.0 \mathrm{mg} / \mathrm{kg}$, ip). Rectal temperature was measured at intervals of 2, 4, $6 \mathrm{~h}$ after the injection of reserpine using an electrical thermometer. Each value shows mean change \pm SEM in body temperature of 12 animals. ${ }^{*} P<0.05,{ }^{* *} P<$ 0.01 compared to reserpine control; ${ }^{\# \#} P<0.01$ compared to control.

Table 1. Effect of TMP on akinesia induced by reserpine in mice $(n=12)$.

\begin{tabular}{lccc}
\hline Groups & Doses & $\begin{array}{c}\text { Exercise } \\
\text { mouse number } \\
(\mathrm{mg} / \mathrm{kg} / \mathrm{d} \times \mathrm{d})\end{array}$ & $\begin{array}{c}\text { Exercise } \\
\text { rates } \\
(\%)\end{array}$ \\
\hline Control & - & 12 & 100.00 \\
reserpine & 2 & 2 & $16.67^{\# \#}$ \\
clomipramine & $40 \times 2+2$ & 7 & $58.33^{*}$ \\
+ reserpine & $20 \times 2+2$ & 3 & 25.00 \\
TMP + reserpine & $70 \times 2+2$ & 7 & $58.33^{*}$ \\
TMP + reserpine & $40 \times 2+2$ & 7 & $58.33^{*}$ \\
TMP + reserpine & $80 \times 2+2$ & \\
\hline
\end{tabular}

${ }^{\#} P<0.01$ vs control; ${ }^{*} P<0.05$ vs reserpine control. 
Table 2. Effect of TMP on ptosis induced by reserpine in mice $(n=12)$.

\begin{tabular}{lcc}
\hline Groups & $\begin{array}{c}\text { Doses } \\
(\mathrm{mg} / \mathrm{kg} / \mathrm{d} \times \mathrm{d})\end{array}$ & Ptosis $(\bar{x} \pm \mathrm{SD})$ \\
\hline $\begin{array}{l}\text { Control } \\
\text { reserpine }\end{array}$ & - & $0.00 \pm 0.00$ \\
$\begin{array}{l}\text { clomipramine } \\
+ \text { reserpine }\end{array}$ & 2 & $3.17 \pm 0.39^{\# \#}$ \\
$\begin{array}{l}\text { TMP + reserpine } \\
\text { TMP + reserpine }\end{array}$ & $20 \times 2+2$ & $0.75 \pm 1.22^{* *}$ \\
TMP + reserpine & $80 \times 2+2$ & $2.00 \pm 1.41^{* *}$ \\
\hline
\end{tabular}

${ }^{\#} P<0.01$ vs control; ${ }^{*} P<0.05,{ }^{* *} P<0.01$ vs reserpine control.

\subsection{Attenuation of 5-HTP-induced HTR by TMP}

Mice only given vehicle showed occasional HTR. The 5-HTP-treated group exhibited markedly and significantly more HTR than control, and the FLU-treated group exhibited markedly and significantly more HTR than 5-HTP control, and the HTR in TMP-treated group decreased markedly but insignificantly in comparison with 5-HTP control (Table 3).

\subsection{Attenuation of 5-HTP + FLU-Induced HTR by TMP}

The result of representative experiment is given in Table 4. As shown in Table 4, 5-HTP induced HTR, and FLU potentiated 5-HTP-induced HTR significantly and strongly, and TMP attenuated FLU-potentiated HTR induced by 5-HTP markedly but insignificantly $(P>0.05)$.

\subsection{Potentiation of NE Toxicity in Mice by TMP}

$\mathrm{NE}$ was injected ip at a dose of $4.0 \mathrm{mg} / \mathrm{kg} 30 \mathrm{~min}$ after clomipramine or TMP. As sown in Table 5, TMP and clomipramine potentiated markedly and significantly NE toxicity in mice.

\section{Discussion}

Forced swim test and tail suspension test are widely used as two animal models of depression to screen new potent antidepressant drugs $[10,13,19,20]$. In forced swim test and tail suspension test, animals under stress conditions from which they can not escape, become immobile after an initial period of struggling. This immobility signifies behavioral despair, resembling a state of mental depression which can be reduced by antidepressant drugs $[10,13]$. In the present study, we investigated the effects of ig administration of TMP on the duration of immobility in rats and mice. TMP at daily dose of $80 \mathrm{mg} / \mathrm{kg}$ for 2 days significantly decreased the duration of immobility
Table 3. Effect of TMP on 5-HTP induced head-twitch responses in mice $(n=12)$.

\begin{tabular}{ccc}
\hline Groups & $\begin{array}{c}\text { Doses } \\
(\mathrm{mg} / \mathrm{kg} / \mathrm{d} \times \mathrm{d})\end{array}$ & $\begin{array}{c}\text { Number of HTR } \\
(\bar{x} \pm \mathrm{SD})\end{array}$ \\
\hline Control & 0 & 0 \\
5 -HTP & 200 & $37.92 \pm 34.80^{\# \#}$ \\
5 -HTP + FLU & $200+40 \times 2$ & $99.42 \pm 58.53^{* *}$ \\
5-HTP + TMP & $200+20 \times 2$ & $20.92 \pm 23.34$ \\
5-HTP + TMP & $200+40 \times 2$ & $22.58 \pm 20.30$ \\
5-HTP + TMP & $200+80 \times 2$ & $17.67 \pm 25.06$ \\
\hline \#\# $P<0.01$ vs control: ${ }^{* *} P<0.01$ vs 5-HTP
\end{tabular}

${ }^{\#} P<0.01$ vs control; ${ }^{* *} P<0.01$ vs 5 -HTP control.

Table 4. Effect of FLU + TMP on 5-HTP induced headtwitch response in mice $(n=12)$.

\begin{tabular}{|c|c|c|}
\hline Groups & $\begin{array}{c}\text { Doses } \\
(\mathrm{mg} / \mathrm{kg} / \mathrm{d} \times \mathrm{d})\end{array}$ & $\begin{array}{c}\text { Number of HTR } \\
(\bar{x} \pm \mathrm{SD})\end{array}$ \\
\hline Control & 0 & 0 \\
\hline 5-НTP & 200 & $37.3 \pm 48.7^{\# \#}$ \\
\hline 5-HTP + FLU & $200+40 \times 2$ & $93.9 \pm 29.5^{* *}$ \\
\hline 5-HTP + TMP & $200+80 \times 2$ & $14.2 \pm 11.2^{@ @ ~}$ \\
\hline 5-HTP + FLU + TMP & $200+40 \times 2+80 \times 2$ & $59.7 \pm 28.7^{@}$ \\
\hline
\end{tabular}

Table 5. Effect of TMP on NE induced toxicity in mice $(n=$ 12).

\begin{tabular}{cccc}
\hline Groups & $\begin{array}{c}\text { Doses } \\
(\mathrm{mg} / \mathrm{kg} / \mathrm{d} \times \mathrm{d})\end{array}$ & $\begin{array}{c}\text { Death number } \\
\text { of animals }\end{array}$ & $\begin{array}{c}\text { Lethality } \\
(\%)\end{array}$ \\
\hline Control & - & 0 & 0.0 \\
$\mathrm{NE}$ & 4.0 & 2 & 25.0 \\
Clomipramine + NE & $40 \times 2+4$ & $7 *$ & 58.3 \\
TMP + NE & $20 \times 2+4$ & 4 & 33.3 \\
TMP+NE & $40 \times 2+4$ & 5 & 41.7 \\
TMP+NE & $80 \times 2+4$ & $7 *$ & 58.3
\end{tabular}

${ }^{*} P<0.05$ vs NE control.

in the forced swim tests in rats and mice (Figures 2 and 3 ) and at daily doses of 40 and $80 \mathrm{mg} / \mathrm{kg}$ for 2 days significantly decreased the duration of immobility tail suspension test in mice (Figure 4). Pretreatment with TMP at the dose of $80 \mathrm{mg} / \mathrm{kg}$ (ig) was almost as effective as positive control, FLU (20 mg/kg, ig).

Simple tests for antidepressant-like activity, such as reserpine-induced hypothermia and hypomotility, 5-HTPinduced syndrome, or potentiation of noradrenaline toxicity are often mechanism-based tests. In the present study, we investigated the effects of ig administration of TMP on the reserpine-induced hypothermia and hypomotility, 5-HTP-induced syndrome, and potentiation of 
noradrenaline toxicity.

The reserpine-induced animal depression model is based on the monoamine hypothesis of depression [21]. Reserpine can irreversibly inhibit the vesicular uptake of monoamines, including noradrenaline, dopamine and 5hydroxytrytamine. As a consequence, hypothermia and hypomotility are observed as the depletion of monoamines stores [22,23]. These syndromes can be antagonized by major classes of antidepressant drugs. In the present study, pretreating mice with TMP at the dose of 80 $\mathrm{mg} / \mathrm{kg}$ for 2 days significantly antagonized reserpineinduced hypothermia. TMP at the doses of 40 and 80 $\mathrm{mg} / \mathrm{kg}$, and clomipramine at the dose of $40 \mathrm{mg} / \mathrm{kg}$, significantly antagonized akinesia and ptosis induced by reserpine. TMP at the dose of $20 \mathrm{mg} / \mathrm{kg}$ significantly antagonized ptosis, but not akinesia. These results suggested that the antidepressant effect of TMP may be mediated via central monoaminergic neurotransmitter system.

It has been observed that the administration of sufficiently large doses of 5-HTP to mice produces spontaneous irregularly occurring head twitches. Head twitches induced by 5-HTP and 5-HT agonists in rats and mice are due to stimulation of central $5-\mathrm{HTz}$ receptors possibly located in brain stem. In the present study, the 5-HTP-treated mice exhibited markedly and significantly more HTR than control, and the FLUtreated mice exhibited markedly and significantly more HTR than 5-HTP control, and the HTR in TMP-treated mice decreased markedly but insignificantly in comparison with 5-HTP control, and TMP attenuated FLU-potentiated HTR induced by 5-HTP markedly but insignificantly. These results suggested that TMP antagonized 5-HTP and FLU. Therefore, the mechanism of antidepressant-like effects of TMP may be different from that of FLU.

Potentiation of lethality in mice intoxicated with NE or yohimbine seems typical of imipramine-like antidepressants since almost all antidepressants studied did show this effect. A test of NE or yohimbine potentiation toxicity in mice reveals an adrenergic component of pharmacological activity of antidepressants. In the present study, TMP and clomipramine potentiated markedly and significantly NE toxicity in mice. Therefore, TMP might be an adrenergic component of pharmacological activity.

Taken together, TMP is one of available blood-activating and stasis-eliminating components from traditional Chinese medicines. This study provides evidences that TMP possesses potent antidepressant-like activity, and it might be an adrenergic component of pharmacological activity, and its mechanism of antidepressant-like action is similar to that of clomipramine, and different from that of FLU.

\section{Acknowledgements}

The authors would like to thank Dr. Depu Yu for his suggestions and great encouragement.

\section{REFERENCES}

[1] L. Bach-Rojecky, Z. Kalodjera and I. Samarzija, “The Antidepressant Activity of Hypericum Perforatum L. Measured by Two Experimental Methods on Mice," Acta Pharmaceutica, Vol. 54, No. 2, 2004, pp. 157-162.

[2] X. Zhong, Q. Mao, Z. Huang and J. Wei, “Anti-Depressive Effect of Suyu Capsules in Mice," Chinese Journal of New Drugs, Vol. 15, No. 15, 2006, pp. 1247-1249.

[3] H. B. Zhong, Y. Pan and L. D. Kong, "Antidepressant Effect of Epimedium Brevicornum Extracts," Chinese Traditional and Herbal Drugs, Vol. 36, No. 10, 2005, pp. 1506-1510.

[4] Q. Mao, Z. Huang, S. Ip and C. Che, "Antidepressant-Like Effect of Ethanol Extract from Paeonia Lactiflora in Mice,” Phytother Research, Vol. 22, No. 11, 2008, pp. 1496-1499. doi:10.1002/ptr.2519

[5] G. Liu, “Chinese Herbal Medicine,” Hua Xia Publishing House, Beijing, 2001, pp. 227-228.

[6] H. B. Li and F. Chen, "Preparative Isolation and Purification of Chuanxiongzine from the Medicinal Plant Ligusticum Chuanxiong by High-Speed Counter-Current Chromatography," Journal of Chromatography A, Vol. 1047, No. 2, 2004, pp. 249-253.

[7] M. Su, Y. Zhou and G. Yang, "Effects of Tetramethylpyrazine on L-Type Calcium-Channel Current and the Intracellular Calcium Concentration in Primary Cultured Hippocampal Neuronal Cells," Chinese Journal of Rehabilitation, Vol. 23, No. 1, 2008, pp. 17-19.

[8] Y. B. Ji, "Pharmacological Action and Application of Blood-Activating and Stasis-Eliminating Available Composition of Traditional Chinese Medicine,” Heilongjiang Science and Technique Press, Harbin, 1999, pp. 118-121.

[9] K. Taghzouti, S. Lamarque, M. Kharouby and H. Simon, "Interindividual Differences in Active and Passive Behaviors in the Forced-Swimming Test: Implications for Animal Models of Psychopathology,” Biological Psychiatry, Vol. 45, No. 6, 1999, pp. 750-758. doi:10.1016/S0006-3223(98)00156-5

[10] R. D. Porsolt, M. le Pichon and M. Jalfre, "Depression: A New Animal Model Sensitive to Antidepressant Treatments,” Nature, Vol. 266, No. 5604, 1977, pp. 730-732. doi:10.1038/266730a0

[11] R. D. Porsolt, G. Anton, N. Blavet and M. Jalfre, "Behaviour Despair in Rats: A New Model Sensitive to Antidepressant Treatments," European Journal of Pharmacology, Vol. 47, No. 4, 1978, pp. 379-391. doi:10.1016/0014-2999(78)90118-8

[12] R. D. Porsolt, A. Bertin and M. Jalfre, "Behaviour Despair in Mice: A Primary Screening Test for Antidepressants," Archives Internationals de Pharmacodynamie et de Therapie, Vol. 229, No. 2, 1977, pp. 327-336. 
[13] L. Steru, R. Chermat, B. Thierry and P. Simon, "The Tail Suspension Test: A New Method for Screening Antidepressants in Mice,” Psychopharmacology, Vol. 85, No. 3, 1985, pp. 367-370. doi:10.1007/BF00428203

[14] J. M. Vaugeois, G. Passera, F. Zuccaro and J. Costentin, "Individual Differences in Response to Imipramine in the Tail Mouse Suspension Test,” Psychopharmacology, Vol. 134, No. 4, 1997, pp. 387-391. doi:10.1007/s002130050475

[15] Z. Yan and Z. Luo, "Experimental Methods of Antidepressant Pharmacology,” In: Q. Zhang, Ed., Experimental methods of Modern Pharmacology, The Press of Medical University of Beijing, Beijing, 1998, pp. 1063.

[16] C. C. Sànchez-Mateo, C. X. Bonkanka, B. Prado and R. M. Rabanal, "Antidepressant Activity of Some Hypericum Relexum L. Fil. Extracts in the Forced Swimming Test in Mice," Journal of Ethnopharmacology, Vol. 112, No. 1, 2007, pp. 115-121. doi:10.1016/j.jep.2007.02.019

[17] C. A. Hubbard and J. M. Trugman, "Reversal of Reserpine-Induced Catalepsy by Selective D1 and D2 Dopamine Agonists," Movement Disorders, Vol. 8, No. 4, 1993, pp. 473-478. doi:10.1002/mds.870080410

[18] E. L. Shelkunov, "Effect of Imipramine-Like Antidepressants on Head Twitching in Mice Induced by 5-Hy- droxytryptophan," Bulletin of Experimental Biology and Medicine, Vol. 86, No. 9, 1978, pp. 1171-1173. doi:10.1007/BF00845019

[19] D. Ahsana and K. Shagufta, "Antidepressant Effects of Ethanol Extract of Areca Catechu in Rodents," Phytotherapy Research, Vol. 11, No. 2, 1998, pp. 174-176.

[20] Y. M. Wang, L. D. Kong and Y. M. Chen, "Behavioural and Biochemical Effects of Fractions Prepared from Banxia Houpudecoction in Depression Models in Mice,” Phytotherapy Research, Vol. 19, No. 6, 2005, pp. 526-529. doi:10.1002/ptr.1697

[21] Q. Mao and Z. Huang, “Antidepressant Drugs and Animal Models of Depression,” Foreign Medical Sciences Section of Psychiatry, Vol. 32, No. 2, 2005, pp. 216-220.

[22] M. Bourin, M. Poncelet, R. Chermat and P. Simon, "The Value of the Reserpine Test in Psychopharmacology," Arzneimittel Forschung-Drug Research, Vol. 33, No. 8, 1983, pp. 1173-1176.

[23] B. Yan, D. Y. Wang, D. M. Xing, Y. Ding, R. F. Wang, F. Lei and L. J. Du, “The Antidepressant Effect of Ethanol Extract of Radix Puerariae in Mice Exposed to Cerebral Ischemia Reperfusion,” Pharmacology Biochemistry and Behavior, Vol. 78, No. 2, 2004, pp. 319-325. doi:10.1016/j.pbb.2004.04.010 